\title{
Sacred Kingship: Cases from Polynesia
}

\section{Henri J. M. Claessen}

Leiden University

\begin{abstract}
This article aims at a description and analysis of sacred kingship in Polynesia. To this aim two cases - or rather island cultures - are compared. The first one is the island of Tahiti, where several complex polities were found. The most important of which were Papara, Te Porionuu, and Tautira. Their type of rulership was identical, so they will be discussed as one. In these kingdoms a great role was played by the god Oro, whose image and the belonging feather girdles were competed fiercely. The other case is found on the Tonga Islands, far to the west. Here the sacred Tui Tonga ruled, who was allegedly a son of the god Tangaloa and a woman from Tonga. Because of this descent he was highly sacred. In the course of time a new powerful line, the Tui Haa Takalaua developed, and the Tui Tonga lost his political power. In his turn the Takalaua family was overruled by the Tui Kanokupolu. The tensions between the three lines led to a fierce civil war, in which the Kanokupolu line was victorious. The king from this line was, however, not sacred, being a Christian.
\end{abstract}

\section{INTRODUCTION}

Polynesia comprises the islands situated in the Pacific Ocean within the triangle formed by the Hawaiian Islands, Easter Island and New Zealand. The islanders share a common Polynesian culture. This cultural unity was established already in the eighteenth century, by James Cook, who observed during his visit of Easter Island in 1774:

In Colour, Features, and Languages they [the Easter Islanders] bear such an affinity to the People of the more Western isles that no one will doubt that they have the same Origin (Cook 1969 [1775]: 279, 354-355).

The French explorer La Pérouse, who visited Easter Island in 1786, confirmed the views of Cook (La Pérouse 1994 [1788], I: 64, 65), as also

Social Evolution \& History, Vol. 17 No. 2, September 2018 3-26

(C) 2018 'Uchitel' Publishing House

DOI: $10.30884 / \mathrm{seh} / 2018.02 .01$ 
did Johann Reinhold Forster, who accompanied Cook as a naturalist in his second voyage and pointed in several places of his Observations to similarities in the languages and cultures of the Polynesians (Forster J. 1996 [1788]: 153, 172, 183), the same holds for his son Georg (Forster G. 1983 [1778]: 535). These eighteenth-century views are agreed on nowadays by the great majority of students of the region (e.g., Campbell 1989; Goldman 1970).

The origins of the Polynesian culture go back about 2,500 years, when small numbers of people, carrying the so called Lapita Culture, left the islands of Melanesia where they had lived for a thousand years or so (Kirch 1997) and reached the Samoa and Tonga Islands in the west of the Pacific Ocean. Here, in isolation, they developed the so-called Ancestral Polynesian Culture which spread in the next thousand years from there over most of the archipelagos and islands of the Pacific (Irwin 1992). Kirch and Green (2001) using archaeological, linguistic and ethnographical data reconstructed this Ancestral Polynesian Culture in great detail. They demonstrate that from its very beginning the Polynesian sociopolitical organization was hierarchically structured. The hierarchy was rooted in the kinship system, in which a number of families (lineages) formed a closely connected whole, usually called a ramage. ${ }^{1}$ Stated in a most simplified way, the concept of ramage structured the Polynesian societies along hierarchical lines, legitimated by the sacredness of the chiefs. So, from its very beginning there was a kind of ranking in and among the families. The oldest family was considered to have the highest status. The leader of this family, the oldest male, was called the ariki (also: ari'i, ali'i). He fulfilled the ritual and political tasks for the group. His position was hereditary, with the eldest son (normally) succeeding to his father's position. It was believed that this eldest line (the first-born line) traced its descent back to the world of the gods (summary from Thomas 1990: 28-33; see also Claessen 2005: 233237; Flannery and Marcus 2012: 208-215, 316-337, 341-348).

In actual practice the branches within a ramage retained their genealogical interrelations, thus facilitating the formation of larger political units under the leadership of a ranking chief (Kirch 1984: 66). Succession in the ramage was determined by primogeniture. Problems could arise if the eldest child was a daughter. Usually she was married off to some high-born elsewhere, where she then often played a powerful political role - as e.g., Purea, married to the ari'i rahi Amo of Papara (Claessen 1978).

There were found several islands in Polynesia with well-developed political organizations, among them the Society Islands, with Tahiti as its centre, the Tonga Islands, and the Hawai'i Islands. Each of these societies has been described by numerous voyagers, missionaries, merchants, go- 
vernmental officials, and later arriving anthropologists and historians. The handling of this great variety of sources asks for a critical eye, for many of the voyagers just described what they saw - or thought they saw, - the manuscripts of the missionaries contain numerous prejudices, the merchants were looking mainly for commercial possibilities, while the governmental officials were mostly interested in 'keeping order' in these 'uncivilized' societies (see for details on the sources Claessen 2000; de Bovis 1980 [1855]: 65-72). In the descriptive parts of this article some of the above comments will be elaborated.

Thus, here is the moment to consider the question to what extent the political leaders of some of the Polynesian societies did qualify as kings. When does one speak of 'king'? This is a difficult problem in anthropology, for the dividing line between a paramount chief and a little king is but thin. I will use the term king for those rulers, who ruled a polity that at least qualifies as an incipient early state. The criteria for incipient early states were developed in The Early State (Claessen and Skalník 1978: 640-642. cf. also Tymowski 2009, passim; Claessen and Hagesteijn 2012: 4-10; Claessen 2015: 3-5). This view with regard to the Polynesian islands is not shared by all anthropologists. ${ }^{2}$ They prefer the term 'chiefdoms', as also Kirch (1984), and Campbell (1989) do. In this article I will use the terms king and kingdoms, evading in this way the terminological pitfalls connected with 'early state'.

A connected question is of course: when do we speak of 'sacred'? On the basis of literature consulted previously (Claessen 1970, 1994, 1995, 2000, 2015; Firth 1967; Goldman 1970; Kirch 1984, 1997; Kirch and Green 2001), several characteristics of a sacred king were identified, such as his influence on fertility - which might be seen as his core business the many prescriptions regarding his person, the ritual role of certain women, his right to appoint human sacrifices, and so on. In this article these characteristics will be considered as hypotheses, which will be tested against the ethnographical data. To make the necessary analyses and comparisons I will use short descriptions of the kingdoms of Tahiti, and the Tonga Islands.

\section{THE TAHITIAN KINGDOMS}

It occurred already to the first European visitors of the island that there were several polities on Tahiti: Wallis, who anchored in 1767 in Matavai Bay at the west coast of the island, met here several notables, among them Purea, a high placed woman (Robertson 1948: 204). ${ }^{3}$ A short time later the French captain Louis de Bougainville reached the east coast, at Hitiaa, and was warmly welcomed here. On the basis of these experiences, as a good follower of Rousseau, ${ }^{4}$ he called the island 'la nouvelle Cythère' 
(Bougainville 1966 [1771]: 205-232). The only negative trait of the Tahitians he noted was the never ending of thieving everything they could lay their hands on - a trait also noted with disfavour by Robertson, and later by Cook.

Going clockwise from Matavai the following important polities can be discerned: Te Porionuu, also called Pare-Arue (of which Matavai was a part), Papenoo, Hitiaa, the peninsula Taiarapu, of which the powerful Tautira was the centre, Vaiari, the eldest polity, the dominant kingdom of Papara (where Purea lived), and the large polity of Atehuru (for a map and detailed comment: Claessen 1978: 447-449).

It can be safely stated that the polities of Te Porionuu, Tautira, and Papara were ruled by kings, called ari'i rahi. The situation in Atehuru is not clear; there were found several high placed notables at the same time. ${ }^{5}$ Between the various notable families a fierce competition for power and later also for religious symbols existed, but also many marriage ties occurred, which makes for a most complicated field of action (Claessen 1994, 1995, 2000). Three aspects were dominant in these struggles: prestige, sacredness, and (political) power, fields in which the leading families eagerly tried to outdo the others. These aspects were not connected, as appears from the position of the ari'i rahi of Vaiari, who, as the leader of the oldest branch, had a high prestige, but had lost all political power (Oliver 1974: 1203; Claessen 1978: 449).

I will present first a description of the data on the various aspects of sacred kingship and then, on this basis, see to what extent the suggestions presented above can be found in Tahiti.

\section{a. Sacred character of the ari'i rahi}

Though the early visitors described their encounters with Tahitian notables, and noted several strange customs, they did not connect these with the sacred character of these persons. The Spanish captain Andia y Varella noted that the lord was 'fed by the hand of another person' (Andia 1775 in Corney 1915, II; 264), the interpreter Maximo Rodriguez tells us that Tahitian fishermen did not dare use a fishing net that belonged to Vehiatua, the ari'i rahi of Tautira (Rodriguez 1995 [1776]: 131). He also mentions human sacrifices (Ibid.: 172, 175). More important are the observations made by James Cook during his four visits to Tahiti (1769, 1773, 1774, 1777). He was accompanied by scholars such as Banks, Solander, and father and son Forster, who all wrote about their experiences at Tahiti. Moreover, several of his crew members wrote reports and kept diaries: the astronomer Wales, the surgeons Anderson and Ellis, and the surgeon's mate Samwell. Most of these reports are only descriptive; the authors reported what they saw, but they knew but little about the background of 
what they saw. On the other hand, as Cook visited Tahiti four times, his knowledge and understanding increased all the time.

Cook mentions a visit by Amo of Papara and his son Teri'irere, who was carried on the shoulders of a man. Everyone was obliged to uncover the shoulders. Amo acted as a kind of regent for his son (Cook 1968 [1771]: 103 ff., 134; 1969 [1775]: 206, 208). Georg Forster (1983 [1778]: 282) likewise mentions that everyone uncovered the shoulders in presence of Vehiatua, the ari'i rahi of Tautira.

Some years later the Bounty mutineer James Morrison (1966 [1792]: $137,138-139$ ) states that the ari'i rahi was a sacred ruler and that everything touched by him became sacred, so that no ordinary person was allowed to use the object concerned any longer. The ruler was connected with the god Tane. In $1788 \mathrm{Tu}$, the ruler of Pare Arue, who was named at that time Tinah, ${ }^{6}$ acted as regent for his son (Bligh 1952 [1792]: 47), who lived in Pare with Tinah's other children. ${ }^{7}$ This son occupied now the highest rank in the island, according to Bligh (1952 [1792]: 51). He was carried on the shoulders of servants and everybody had to uncover the shoulders in his presence (Bligh 1952 [1792]: 53; Morrison 1966 [1792]: 138). The great reverence for the son did not change the power position of the father, however, and though several of his sacred aspects remained, the father could now walk along and was no longer carried on the shoulders of a servant (who was protected by some ritual to the sacred influence of the prince). Captain Bligh mentions (as also had Andia, see above) that the ari'i rahi sometimes was fed by a servant (Bligh 1952 [1792]: 48, 55; 1988 [1793]: 82), as he was not allowed at that moment to touch food himself.

In the war between Papara and the other princedoms, Papara lost and as a consequence its ruler lost prestige and power. Worse was that Papara also lost its Oro image and the connected feather girdle (on Oro see below). After some time, Teri'irere, the son of Amo and Purea seems to have restored the position of Papara (Oliver 1988: $159 \mathrm{ff} ., 215)$.

The missionary Ellis (1831, III: 94) states that the god (Oro?) and the king were generally supposed to share the authority over mankind. 'The latter sometimes personated the former, and received the homage and the requests, and at other times officiated as the head of his people, in rendering their acknowledgements to the gods. Their persons were always sacred'. He adds to this that the genealogy of the reigning family was usually traced back to the first ages of their traditional history. In some cases it was supposed that the king was descended from the gods. The missionaries of the Duff ${ }^{8}$ several times mention that the young Tu and his wife were carried on men's shoulders (Wilson 1799: 62, 63, 64, 200 ) and that they never entered a house or came aboard the ship because of their sacredness (Ibid.: 63, 65, 67, 329). 


\section{b. The god Oro and the Feather Girdles}

Though the Tahitian princes originally were connected with the god Tane, in the course of the late seventeenth century the old gods were eclipsed by the arrival of a new god, Oro, a descendant of the high god Ta'aroa. This worship had originated on the island of Ra'iatea, west of Tahiti. Oro was from the beginning associated with war, and with feather girdles, the maro ura (red feathers) and the maro tea (yellow feathers) (Oliver 1974: 891 ff., 904; Rose 1978). The possession of an Oro image and one of the maro's was important for an ari'i rahi for only this made it possible for him to offer human sacrifices in temples dedicated to Oro (Oliver 1988: 49, 117, 145). This explains how serious the loss was for Papara of the Oro image and the maro tea. ${ }^{9}$ The fierce struggles between the great powers in Tahiti during the first decades of the nineteenth century were all caused by the necessity to conquer - and to keep - one of the images and one of the girdles. In the end it was the rulers of PareArue who succeeded to get them all (Morrison 1966 [1792]: 81-83; Claessen 1995: 287).

\section{c. Inauguration of an ari'i rahi}

Morrison was the first and only visitor who witnessed such a ceremony in 1788. The young king of Pare Arue was then invested with the maro ura by the chief priest (Morrisson 1966 [1792]: 91), who put the maro around the hips of the young prince and hailed him as the great ari'i rahi of Tahiti. Three human sacrifices were offered, and an eye of each victim was presented to the prince. Interestingly, Morrison does not mention the coming of the two sharks, supposed to swim around the young ari'i during the ritual as mentioned by Moerenhout, Ellis, and Henry (Moerenhout 1837: ii: 26; Ellis 1831: iii: 111; Henry 1951 [1928]: 200) who none of them actually witnessed such a ceremony. After this part of the inauguration there is a kind of continuation on the beach, during which members of the Arioi society play a peculiar kind of honouring the new ruler - an activity which is prudently couched in veiled wordings by the missionaries. Moerenhout, however, presents details of these activities. He refers to dances during which

plussieurs hommes et femmes entièrement nus, entouraient le roi, et s'efforcaient de le toucher des différents parties de leur corps, au point qu'il avait peine à se preserver de leur urine et de leurs excrémens, don't ils cherchaient à le couvrir (Moerenhout 1837 II: 27).

Moerenhout got this information apparently from some Tahitians, for he was not there himself. The French anthropologist Alain Babadzan (1993: $188 \mathrm{ff}$.) sees this ritual as an effort to make the sacred ruler human 
again. Also the missionary Ellis (1831, III: 108-113) gives a detailed report on the inauguration ceremonies and emphasizes the role of the priests in the activities (but does not describe the activities of the Arioi).

\section{d. Human sacrifices}

On his second visit James Cook saw a human corpse in a marae (Cook 1969 [1775]: 233-234, 238), and was told that such offerings were demanded by the priests. Something similar is described by J. R. Forster (1996 [1778]: 328-330). Also on his third voyage a human sacrifice was prepared to be offered to Oro in a marae at Atehuru. Cook and some of his men attended the ritual (Cook 1967 [1778]: 198-202). Also here a priest played a central role: he held up a maro and a bundle containing the Oro image. An eye of the person sacrificed was offered to Tu, and in the end the victim was buried. It was stated (by the priest) that people to be sacrificed were selected among the lower class and were killed by surprise (Cook 1967 [1778]: 209). Some years later some sacrifices were attended to by William Bligh, whose descriptions are similar to those of Cook. He adds that the absence of Tu prevents anything being done until he returns and the eye can be presented to him (Bligh 1988 [1793]: 124, 150). He mentions the name of the officiating high priest: Ha'amanemane. He was told that these offerings were a token of thanks for a victory (1988 [1793]: 124).

The British merchant, John Turnbull, states that especially the ari'i rahi Pomare (the new name of $\mathrm{Tu}$ ) insisted on this kind of sacrifices (Turnbull 1806: 324). The victim was not usually killed by the priest, but by one of the ruler's servants. De Bovis thinks that the victims were killed at the request of the high priest (De Bovis 1980 [1855]: 51). Contrary to this is the view from Ari'i Taimai that only an ari'i rahi could order human sacrifices to be offered (Ari'i Taimai 1964 [1901]: 13).

\section{e. First Fruits}

Cook gives a first indication of the occurrence of first fruit offerings, for he says:

I am of the opinion that they offer to the Eatua (atua) a strip or small piece of every piece of cloth they make before they use it themselves and it is not unlikely but what they observe the same thing with respect to their Victuals (Cook 1968 [1771]: 135).

The Bounty mutineer Morrison (1966 [1792]: 151) is more explicit; according to him

Les premiers fruits de toutes sortes sont offerts au dieu puis au chef et au Seigneur du lieu avant d'être consommés et il est de 
même pour les poisons [...] les premiers poisons pêchés vont toujours au marae où ils sont offerts par le prêtre avec des prières.

He adds that the first pig was offered, as well as the first chicken.

De Bovis (1980 [1855]) mentions the custom of holding a festival in springtime, when the Tahitians would offer the first of their fruits. According to Moerenhout (1837, i: $517 \mathrm{ff}$.), the first fish of the season was offered to the gods; the next day's catch was for the chiefs. The first fruits were offered at the end of December. Only a small part of the offerings went to the gods, the remainder being given to the ari'i rahi, who in his turn distributed the food and other offerings among the priests, the nobles, and common people (Moerenhout 1837, i: 520). Henry (1951 [1928]: $185)$, and the missionary Ellis (1831, i: 350$)$ present similar data.

\section{f. Fertility}

The view on the relation of the kings with fertility varies somewhat between the sources. There are no indications about it in the early sources. Only in the descriptions of the Arioi society some remarks on fertility are found, though most comments concentrate on their indecent dances and sexual activities. William Bligh however, stresses that the members of the society are highly respected (Bligh 1952 [1792]: 56, 63, 90, 96). Morrison (1966 [1792]: 195) characterizes the society as a society composed of young people, 'qui consacrent leur jeunesse à une vie de plaisir et de débauche.' He adds that Arioi members never participated in wars (Ibid.: 196). Henry (1951 [1928]: 76-95, 237) connects the society with the god Oro 'of the downward lances' indicating in this way the peaceful aspect of both Oro and the society. The British merchant Turnbull on the other hand describes the Arioi as

eine so zügellose und verruchte Gesellschaft, das man glauben sollte, sie würde die Strafe des Himmels auf sich herabrufen. Die Hauptgrund ihrer Verbindung ist die Gemeinschaft der Weiber, und die Ermordung aller von ihnen erzeugten Kinder beiderlei Geschlechts, sogleich nach ihrer Geburt (Turnbull 1806: 267-269).

It is, however, Moerenhout (1837, ii: 131), who points out that the obscene and wanton dances somehow were intended to represent fertility. Oliver (1974: 1023) casts doubt on the fertility hypothesis, which, however, in my opinion is not improbable.

Yet the matter of influence on fertility by the king remains unclear. If the suggestion is accepted that the Arioi society did play their games with the idea of fertility in mind we see that most kings were for some time member of the society. The necessity to produce a successor ended their 
membership after some years (Bligh 1952 [1792]: 56, 57). The first fruits that were offered to the king can be interpreted as a kind of thank offer for his influence on fertility - for without the interference of the ruler by the gods the food production will be in danger - an interpretation strongly influenced by the views of Nicholas Thomas, who analyzed in detail the sacred position of Polynesian chiefs (1990: 32).

\section{g. Ritual Women}

There have not been found indications for the existence of women with a ritual position in Tahiti. Women were even not allowed to enter a marae.

\section{h. Priests}

As in numerous cases priests played a role in the royal rituals, some attention to these functionaries seems justified. Priests were supposed to possess great religious and ritual knowledge, so a thorough schooling was necessary; a condition emphasized by Oliver (2002: 42-52). At the head of the priests of a certain marae stood a high priest or tahua rahi. De Bovis (1980: [1855]: 46) suggests that the ruler who owned the temple delegated his religious and ritual tasks to a family member - who thus became the high priest - as the combination of priestly and political tasks was too heavy for a ruler. Apart from his priestly obligations the tahua rahi was also a close advisor to the ruler. The high priest Ha'amanemane was such an advisor. It is not clear how a prince, appointed as a tahua rahi, could have achieved the necessary priestly knowledge, for candidates for the priesthood normally followed a lengthy and demanding schooling. They had to memorize the many prayers and rituals, and when performing them they had to be letter perfect (Oliver 1974: 86; Henry 1951 [1928]: 162). One might suppose that most of these requirements were skipped when the candidate was a prince. Apart from the high priest there were several lower ranking priests attached to the marae assisted by a number of lay servants.

\section{Summarizing}

There were found a great number of statements with regard to the sacredness of the Tahitian kings. It was not allowed to touch them; their houses were tapu ${ }^{10}$ Anything they touched became forbidden. They should not touch the soil and thus were carried on the shoulders of men. Everybody should uncover the shoulders in the presence of the king, even the parents of the ruler were obliged to do so. Several sources state that the ari'i rahi were related to the gods. This might explain the many prescriptions and obligations surrounding them.

In the eighteenth century this was the god Oro, who originated in Ra'iatea. With Oro came the necessity for the rulers to acquire the idol and the connected feather girdle (maro). These attributes were needed for the ruler when he wished to bring human sacrifices. Several visitors wit- 
nessed human sacrifices. The whole ceremony was played in an Oro temple. A priest offered the victim by presenting an eye to the presiding king. In fact by each important ceremony a human sacrifice was offered.

It was also the god Oro who played a central role in the inauguration of an ari'i rahi, the high priest then showed the idol and clad the incumbent with a maro. After that there were ceremonies in the nearby Oro temple during which members of the Arioi society played a peculiar role. Some sources connect these activities with a fertility ritual. The views on the Arioi society vary greatly. Those of the sources who see especially their obscene activities reject this possibility; those who try to understand the society are willing to accept their role in fertility rituals.

The fact that all kinds of first fruits were offered to the ruler is an indication that he somehow is connected with fertility - a quality which is usually ascribed to sacred rulers. It was thanks to the ritual activities of the ruler that food could be produced.

In view of the data presented above it is clear that the arii rahi from Tahiti can be considered as sacred kings, a sacredness coming to the fore especially in their assumed relation to the gods, their being tapu, their capacity to have human sacrifices offered and in their connection with fertility. ${ }^{11}$

\section{THE TONGA ISLANDS}

The Tonga archipelago is situated far west of the Society Islands. With the Samoa islands they were the first islands settled by the Lapita people, coming from Melanesia. According to the archaeologist David Burley (1998: 351) this happened about 900 B.C. According to Patrick Kirch (1984: 219) this must have been about 1200 B.C. There is agreement, however, about the characteristics of the Lapita culture. Kirch (1997: 189) thinks 'that birth order was an important social criterion among the Lapita peoples.' This would imply 'an early form of hereditary leadership, in which rank or authority was passed from one generation to the senior offspring of the next' (Kirch 1997: 189; $c f$. Kirch and Green 2001: 226-235).

Some time after their arrival the Lapita peoples left the coasts, and started to live inland (Campbell 1992: 5; Burley 1998: 354-355). From the earliest times the Tongans must have lived under chiefs. There is not much known about this period. The proliferation of burial mounds is an indication of a considerable population growth, while the increasing number of faitoka's (burial monuments) points to a growing number of chiefs (McKern 1929: 30; Poulsen 1977: 12). It can be assumed that shortly before A.D. 1000 all available agricultural land would have been under production (Kirch 1984: 222). Under these conditions inter-group competition must have taken place, 'leading ultimately to assimilation of 
weaker groups by stronger and larger ones' (Ibid.: 223; 1988: $423 \mathrm{ff}$.). The period of the chiefs made place for the period of powerful kings, the tui tongas.

The development of this category of rulers comes to the fore in the emergence of a new type of burial monuments, the langis, enormous stone buildings, described and pictured by many European visitors (see e.g., Campbell 1992: 11). Also a new residence was build, the village of Lapaha (Burley 1998: 372; Claessen and van Bakel 2006: 226). Near to Lapaha the enormous trilithon Ha'amonga-a-Maui was erected. The construction of such huge monuments could only have been possible under a centralized power, with the means to have available a large workforce.

\section{The Tui Tonga}

According to the traditional history - based on oral traditions and genealogies - the line of the tui tonga was founded about A.D. 950. The first tui tonga, Aho'eitu, was the alleged son of a Tongan woman, Ilaheva, and the sky god Tangaloa. This descent was certainly sufficient to make the tui ton$g a$ a sacred person. There is not yet developed a satisfying explanation of this sacred marriage. Most modern scholars think that the god in reality was a foreigner, passing some time at Tongatapu. This is too simplistic to be the complete story behind this fortunate meeting. This hypothetical stranger must have been a man of high standing; perhaps a prince from a nearby kingdom, being as such a sacred person himself. He must also have been acceptable to the father of the girl - who, not improbable - was the daughter of a mighty chief. In view of this high (sacred) rank, the son, Aho'eitu, was eligible for the succession and so became the first tui tonga. To what extent this hypothetical story is true cannot be known; but it at least tries to explain the miraculous story of the origin of the tui tonga line.

The year A.D. 950 was calculated by Gifford (1971 [1929]: 49-59) who offers a thorough review of the dynasty and states that 39 generations can be distinguished. Taking this number of rulers, and estimating their average rule at 30 years, working back from the last tui tonga, who died in 1865 , he finds that the first tui tonga most probably must have begun his reign about that date. ${ }^{12}$

\section{a. The sacred king}

The tui tonga was without doubt a sacred king, surrounded by numerous tapus. His mana ${ }^{13}$ is so strong that he is surrounded by many ritual measures to protect his people against the danger of it. It is the tui tonga not allowed to enter the house of anybody else, for it would then become sacred, and no longer free to be entered by ordinary people. This is why always some small houses are carried with him (Mariner 1819: 442; Gifford 1971 [1929]: 71). Interestingly, this prohibition apparently does not hold for European ships, for Paulaho, the tui tonga in the period of 
Cook's visits, several times visited the ships, but these did not become tapu for his people (Maurelle 1782 [1797]: 285, 297). It is not allowed to touch the king, and certainly not his dead body. This interdiction holds even for the highest notables (Mariner 1819: 487; Dumont d'Urville 1832, iv: $305 \mathrm{ff}$.). In case they break this rule, they must be fed by somebody else for a period of ten months (Mariner 1819: 483, 487; Dumont d'Urville 1832, iv: 305 ff.). Hair rests, nail clippings, and the royal saliva are also highly sacred, and the Tongans are afraid to touch these (Wilson 1799: 242). They are buried in a separate hill, near the house of the king (McKern 1929: 96). Related to these tapus is the prohibition for the tui tonga to be tattooed, or circumcised, for his blood is too sacred to be spilled in such rites. ${ }^{14}$ Connected with these rules is that the king does not act as war leader; this task is fulfilled by one of the notables (Dumont d'Urville 1832, iv: 91 ff.). Those who violate one of the many tapus surrounding the tui tonga run the risk of sickness or even death. Only the king himself could lift the curse (Mariner 1819: 489; Dumont d'Urville 1832, iv: 306 ff.; Gifford 1971 [1929]: 119. 125). This is done in the moei-moei ceremony. Here the culprit touches the soles of the king, first with his hands and then with his head. The king is not allowed to deny the culprit. As the moei-moei ceremony is also a sign of reverence to the king, this is sometimes a heavy duty for him, when several people want to express their allegiance in this way (Dentrecasteaux 1808, i: 306; Labillardière 1800, ii: 162-63; Dumont d'Urville 1832, IV: 65, 235).

Those of a lower rank are not allowed to eat in the presence of the king. When food is offered aboard a ship, the lower ranked would leave the hut, or even the ship (Mariner 1819: 489; Dentrecasteaux 1808, i: 284, 306; Labillardière 1800, ii: 117). Sometimes there are large festivities during which great masses of food are distributed. The lower ranked either take the food home, or eat with the back to the king (Mariner 1819: $131 \mathrm{ff} .$, 135, 162, 474, 562; cf. Sahlins 1972 [1958]).

\section{b. Relations with the gods}

The tui tonga is a descendant of the sky god Tangaloa. It is not clear whether this descent did make him a god, or godlike. Some of the sources deny a godlike status (Mariner 1819: $403 \mathrm{ff}$.). Others, such as the missionaries of the Duff, think that the Tongans considered him a god (Wilson 1799: 252). Dumont d'Urville (1832, iv: 293) sees in the tui tonga a god of a lower rank. To what extent the many tapus and prescriptions surrounding the king have played a role in these interpretations is unclear - but not improbable.

In some respects the tui tonga is a kind of priest. He can lift the curses on the breaking of tapus, and when a person thinks he (or she) is pos- 
sessed by a god or spirit it is the king who has to recognize this, which makes the possessed one a priest (Gifford 1971 [1929]: 317).

Finally, it is the tui tonga who is offered the first fruits during the inasi ceremony (see below).

\section{c. Inauguration}

'The successor of the tui tonga was his son born of the great royal wife, a woman who had been properly espoused to him, and was usually the daughter of a great chief... Should there be more than one wife whose children were eligible, the succession went to the first born son, and after him to his younger half-brother, not to his son' (Gifford 1971 [1929]: 61). This 'great wife' was called moheofo (Bott 1982: 99). Since the thirtieth tui tonga the king married a daughter of the tui haa takalaua or the tui kanokupolu, the actual political rulers of Tonga; the tui tonga himself had lost his political power and had to content with his religious position (Claessen 1988: 441; Bott 1981: 33, 52, 53; 1982: 99).

The young prince did not succeed automatically to his dignity. He had to wait till during a special kava ceremony the bowl was oriented towards him, and after that he was formally called by his title as tui tonga (Gifford 1971 [1929]: 61). ${ }^{15}$ After that he goes to his own place, where he fulfils some not mentioned rituals. His sister, the tui tonga fefine (see below), takes a ritual bath in a nearby water (Dumont d'Urville 1832, iv: 108). This bath is probably a necessity to wash away the shame that not she, who is higher in rank than her brother, but he is appointed tui tonga. This is connected with the Tongan custom that sisters are higher in rank than brothers and father's sisters are even higher in rank (cf. Rogers 1977; Kaeppler 1971).

\section{d. Human sacrifices}

Human sacrifices did occur at the Tongan Islands. According to Gifford (1971 [1929]: 321) there were several occasions where such sacrifices were deemed necessary, such as in efforts to secure the recovery of a great chief from illness, the death of the widows of a great chief, and on occasion of the dedication of certain temples. Wilson (1799: 238-239) describes the killing of some young men to achieve the recovery of old Mumui (the then tui kanokupolu). Mariner (1819: 178, 211-212, 313) mentions several cases of killing people, and one of a child to appease the gods. Gifford (1971 [1929]: 322) describes in some detail the interment of living persons in the tomb of a tui tonga. It is not possible to give indications about the actual number of victims.

\section{e. First Fruits}

The ceremony, the inasi, which was witnessed and described by Cook (1967 [1778]: 151-154) and Anderson (1967 [1777]: 913-917), never 
became very clear to the Europeans ( $c f$. also Thomas 2003: 329). Though in many respects it was a religious ritual, in the case Cook witnessed there was also a political aspect in it, for on this occasion the crown prince was allowed to eat together with his father, Paulaho. This act made him alike in rank with the tui tonga. An unheard precedent, for eating together with the tui tonga was strictly forbidden (Labillardière 1800, ii: 347). Cummins (1977: 66) suspects that Tupoumoheofo, the great wife of Paulaho, instigated this move, to ensure the succession of her son.

Normally the offering of yams during the inasi was a first fruit ritual: 'expressions of thanksgiving were offered for past and present bounty and for anticipated future provision of need' (Cummins 1977: 75; Gifford 1971 [1929]: 76, 102 ff.; Wilson 1799: 272, 277). Mariner (1819: 470475 ; 360) presents a detailed description of the inasi, and states that enormous quantities of yams are offered to the gods via the tui tonga, in order to get their protection of the harvest. Cook's artist Webber made an interesting drawing of the rows of people carrying sticks on which yams hanged. After the ceremony the food is distributed to the priests, the tui tonga, the notables and the people. All islands, villages, and notables are obliged to partake in the offerings, which is a heavy obligation. Finau, the new ruler of the Ha'apai Islands, decides therefore to abolish this taxation, which was a heavy burden on his people.

\section{f. Fertility}

The principle of the influence on fertility of the tui tonga was presented already in the previous section. The king had no magical influence on fertility. He, however, was the one who expressed the thanks of his people to the gods for their aid and implored these to continue to give fertility to the land.

\section{g. Ritual Women}

This is a complex subject. In the strict sense of the word there were no ritual women in the Tonga Islands. Some, it is true, could become possessed by a ghost or a god, and become priestesses (Gifford 1971 [1929]: 76, 317; Dumont d'Urville 1832, iv: 299). However, the most important woman in Tongatapu was the sister of the tui tonga. This was based on the 'basic principle of rank that sisters have a higher rank than brothers' (Bott 1981: 17). 'The father's sister has ritual mystical power over her brother's children' (Ibid.: 18). This holds also for the tui tonga: his sister, the tui tonga fefine, had a higher rank than he (Ibid.: 32). ${ }^{16}$ This situation caused much surprise to the European visitors. Cook met with the tamaha (1967 [1778]: 136), and the tui lakepa, the children of the tui tonga fefine Sinaitakala III. The French visitors Labillardière (1800, ii: 123) and Dentrecasteaux (1808, i: 293) met with Nanasipau, the sister of Paulaho, the then tui tonga, and noted her high rank with surprise. The missionaries of 
the Duff met the tui ardeo, the son of Nanasipau, also noting his high status with surprise (Wilson 1799: 231, 265). According to Bott (1982: 32) the special position of the sister of the tui tonga, and her children was a comparative late phenomenon in Tongan history, which she connects with an effort of the tui tonga family to form a counterweight against the newly developing powers (the tui haa takalaua, and the tui kanokupolu; for details Claessen 1988: 439-442). These royal sisters and her children had a high status, but no political power, as they had been married to a Fijian chief, which prevented this. Since the decline of the tui tonga, also the importance of his female relatives diminished.

\section{h. Priests}

In the above sections it was remarked already that the tui tonga was a kind of priest; he could lift a curse, and those who were possessed he appointed as priests. Mariner (1819: 422) states emphatically that the king was a priest, where Gifford (1971 [1929]: 76) has serious doubts about his priesthood. There must have been, apart from the king, also 'professional' priests, who served the many temples, advised the king and his notables, and took care of the religious needs of the population. Mariner mentions in several places such priests without, however, being more specific, and the same holds for Gifford.

\section{Summary}

The tui tonga was, without doubt a sacred king. His alleged descent from the sky god Tangaloa is sufficient to substantiate this point. As a consequence he was surrounded by a great many tapus. Things he touched became sacred; he is not supposed to enter anybody's house, for it would become forbidden to anybody else. Special care is taken with his hair rests, nail clippings and saliva, which are interred in a special hill. People are forbidden to eat in his presence; they have to leave the room, or abstain from eating. One may wonder how he conducted his sexual life, for apparently his women become not untouchable by her contacts with him.

The succession of the tui tonga is relatively simple: it is the eldest son of the principal wife who will succeed. If there are more sons eligible, it will be the one who most approaches the position of the eldest. The actual inauguration takes place when during a kava circle the bowl is oriented towards him, and the leader of the circle calls his name and rank.

Human sacrifices are mainly brought in case of sickness of a king or other high placed person. In such cases a son, or a child, is killed to move the god who had send the illness to have pity - which but seldom happens.

During the inasi ceremony great quantities of yams are offered via the tui tonga to the gods, to thank for the bounty, and to pray for continu- 
ing blessing. It is thus not the tui tonga who procures fertility, but it is he who asks for it.

Ritual women were not found in the Tonga Islands. There were, however, some women with an extraordinary high position, namely the tui tonga fefine and her children. They had a higher status than the tui tonga, who was obliged to bring them the moei-moei greeting, which he detested greatly.

Regarding priests it must be said that the position of the king in this respect is not clear. As he, however, could fulfil some priestly tasks, he might be considered a priest. Those who became possessed by a ghost or god, were designed as priests by the tui tonga. There must have been according to the sources - numerous priest in the islands, about whom is not much known besides there existence.

The life of the tui tonga was not without risks. Several of them were murdered (Campbell 1992: 15), among them the $23^{\text {rd }}$ ruler, Takalaua, who ruled about A.D. 1450. His successor experienced radical innovations in government by having to accept that his temporal authority went to his younger brother, who from then on used the title of tui haa takalaua (Campbell 1992: 16-17). For the king remained only his sacral aspects (Gifford 1971 [1929]: 56). The position of the tui tonga remained necessary, however, for his sacred position guaranteed fertility, and his status as king legitimized the secular ruler, the hau. In later years the tui haa takalaua was pushed out of his position by a younger brother, the tui kanokupolu. Between the three top notables, a lot of tension and envy existed - as described by Cook, who tried in vain to understand this complex of jealousy and regret (Cook 1967 [1778]: 174-1750; $c f$. Cummins 1977: 65-66; Claessen 1988: 439-441). This delicate situation finally culminated in a civil war, during which Paulaho tried to regain his former position by force, but lost against the kanokupolu group, and had to leave Tongatapu. The last tui haa takalaua died in these years so that in the end only the tui kanokupolu remained, who, with the help of the missionaries of the London Missionary Society (Wilson 1799) succeeded in creating a new, more modern form of government. ${ }^{17}$ The line of the tui tonga ended in 1865, with the death of Laufilitonga (Gifford 1971 [1929]: 50).

\section{THE KINGS COMPARED}

Though at first sight there are many differences between the Tahitian rulers and the ruler of the Tonga Islands, this is not the case when one looks at the essentials. It can be established that both types of rulers were considered as sacred. This idea was based on the alleged descent of one of the gods. As a consequence they were all surrounded by many tapus. These tapus show many similarities - which is obvious, for the variation in this kind of protective measures is relatively limited. ${ }^{18}$ Different is the Tahitian 
custom that an ari'i rahi hands over the kingship, with its numerous ceremonial obligations, to his new born son and continues to rule, without the formal hindrances. The life of these kings is not without danger. In Tahiti there are fought numerous wars between the kingdoms, and several tui ton$g a$ have been murdered. In both cases succession is relatively simple: it is the first born son of the head wife of the king. When there are more sons with more or less equal ranks the succession goes to the one who comes most near the ideal.

The inauguration of a new king differs considerably between Tahiti and Tonga. In Tahiti there is quite a ceremony during which the high priest dons the incumbent in the sea with a maro and after that a fertility ritual takes place with members of the Arioi society. In Tonga it is during a kava circle that the new ruler is named. The connection with fertility is shown in Tahiti apart from the inauguration, in offering the first fruits to the gods. The Tongan king receives yearly great masses of yams during the inasi ritual, which are offered to the gods and later consumed by the participants.

A great difference is that in the Tongan culture the sisters have a higher status than the brothers. The highest status has father's sister. Everybody, and thus also the king, has to show her deference.

Another point of difference is that the Tongan king in the course of time lost his political power to his younger brothers, first the tui haa takalaua, and later to the tui kanokupolu. In Tahiti a ruler could lose his kingdom to a stronger king, though in the case of Papara the defeated rulers succeeded in regaining their position. Finally, however, the rulers of Te Porionuu got the whole of Tahiti in their power.

In Tahiti as well as in the Tonga Islands human sacrifices were brought.

\section{NOTES}

${ }^{1}$ There have been written numerous books and articles on the phenomenon of the ramage. Among these: Firth (1963 [1936]), Sahlins (1972 [1958]), Goldman 1970.

${ }^{2}$ Critical comments on this view are found, for example, in Grinin 2003; 2009; 2011; Bondarenko and Korotayev 2003, passim. In both cases it is mainly the small size of these polities which raises their doubts.

${ }^{3}$ Purea was the wife of Amo, the ari'i rahi of Papara, a polity situated at the south coast. As Captain Wallis was ill during his visit, the details of his stay are fond in the reports of Robertson, the master of the Dolphin.

${ }^{4}$ Jean Jacques Rousseau, an eighteenth century French philosopher, strongly idealized the state of nature. See on Rousseau and his views in relation to Tahiti: Dorsenne 1929: IXXX. On Rousseau in general: Flannery and Marcus 2012: IX-XI.

${ }^{5}$ Oliver (1974: 34) presents the following estimation of the number of inhabitants in the years of their discovery; Pare-Arue - 4,176, Tautira-Teahupo'o - 9,396, Papara 4,685 . The total population is estimated by Oliver at 35,366 people. These data are 
based on surveys by the Missionaries of the Duff (Wilson 1799: 89 ff., and Cook 1969 [1775]: 409). In the beginning of the nineteenth century, according to Norma McArthur (1968: 242-255), the number of inhabitants strongly diminished because of several introduced sicknesses.

${ }^{6}$ The Tahitian rulers changed their name regularly, which caused a lot of confusion.

${ }^{7}$ It was customary that once a son was born to a ruler, he abdicated and turned the whole burden of sacrality on the new born son so that he now - as a regent - could rule without the encumbrance of his sacred status.

${ }^{8}$ In 1797 a Group of Missionaries from the London Missionary Society reached by the ship Duff, Captain James Wilson, Tahiti, while a second Group of Missionaries was brought to the Tongan Islands. The experiences of the Missionaries are compiled by William Wilson, the First Mate on the Duff from the journals of the Missionaries (Moschner 1966: v, vi).

${ }^{9}$ The complex relations between Oro, the feather girdles and the Arioi society are analysed in detail in Claessen (1995).

${ }^{10}$ Tapu was a widespread belief in Polynesia that things belonging to the ari' $i$ rahi were forbidden to be touched by the people. This held for his house, his canoes, his fishing gear and his name. The ruler should not touch the soil, for that would make it forbidden to his people; therefore he was carried on the shoulders of men.

${ }^{11}$ This aspect is strongly emphasized by Nicholas Thomas in his analysis of Polynesian chiefship (Thomas 1990: 29-31).

${ }^{12}$ On Gifford's computation several historians and anthropologists have critically commented: Phyllis Herda (1990: 23) severely criticised Gifford but gives no alternative; Burley (1998: 370) adds archaeological data to the genealogical; Campbell (1992: 7) prefers an average of 25 years.

${ }^{13}$ Mana. According to Codrington (1969 [1891]: 118) mana is 'a supernatural power or influence. This is what works to affect everything which is beyond the ordinary power of men, outside the common processes of nature'. Van Baaren (1960: 112 ff.) emphasizes that mana is always connected with a person. Lehmann (1915: 59) characterizes it as 'das ausserordentlich Wirksame'. See Lindstrom (1996: 346) for a survey of opinions.

${ }^{14}$ According to Gifford (1971 [1929]: 75) the king sometimes went to another island (Samoa?) to be circumcised, and Mariner states (1819: 516) that the king was tattooed in Samoa. Cf. Dumont d'Urville (1832 iv: 267); Koch (1955: 60).

${ }^{15}$ Mariner (1819: 330-331) reports a similar ritual during the inauguration of Finau, the chief of the Ha'apai Islands.

${ }^{16}$ For detailed discussions of this relationship: Rogers (1977); Kaeppler (1971); Koch (1955: 70 ff.). A good description of this relationship is given by Thomson (1894: 292-294).

${ }^{17}$ Detailed accounts of this period are given by Campbell (1992: 37-50); Kirch (1984: 223-229); Claessen (2015: 32-33); Cummins (1977).

${ }^{18}$ When compared with the protective measures surrounding African sacred kings the similarities are great, and also here the variation per kingdom is limited as is shown in Claessen (2015). 


\section{REFERENCES}

Anderson, W. 1967 [1777]. A Journal of His Voyage Made in His Majesty's Sloop Resolution. In Beaglehole, J. C. (ed.), The Journals of Captain James Cook; The Voyage of the Resolution and Discovery, 1776-1780 (pp. 721-986). Cambridge: University Press [Hakluyt Society Extra Series 36].

Andia y Varella, J. 1915 [1775]. Narrative 1774-1775. In Corney, B. G. (ed.), The Quest and Occupation of Tahit by Emissaries of Spain during the Years 1772-1776. Vol. 2 (pp. 224-231). London: The Hakluyt Society [ $2^{\text {nd }}$ Series 36].

Arii, Taimai. 1964 [1901]. Mémoires d'Arii Taimai. Paris: Musée de l'Homme [Publications de la Société des Océanistes 12].

Baaren, Th. van. 1960. Wij Mensen; Religie en wereldbeschouwing bij schriftloze volken. Utrecht: Bijleveld.

Babadzan, A. 1993. Les dépouilles des dieux; Essai sur la religion Tahitienne à l'époque de la découverte. Paris: Maison des Sciences.

Bligh, W. 1952 [1792]. A Voyage to the South Seas. In Mackaness, G. (ed.), A Book of the Bounty (pp. 1-110). London: Dent.

Bligh, W. 1988 [1793]. The Providence Journal. In Oliver, D. (ed.), Return to Tahiti; Bligh's Second Breadfruit Voyage. Honolulu: University of Hawaii Press.

Bondarenko, D. M., and Korotayev A. V. 2003. 'Early State' in CrossCultural Perspective: A Statistical Re-Analysis of Henri J. M. Claessen's Database. Cross-Cultural Research 37: 104-131.

Bott, E. 1981. Power and Rank in the Kingdom of Tonga. Journal of the Polynesian Society 90: 7-82.

Bott, E. 1982. Tongan Society at the Time of Captain Cook's Visits. Discussions with Her Majesty Queen Salote Tupou. Wellington: Polynesian Society.

Bougainville, L.-A. de. 1966 [1771]. Voyage autour du monde par la frigate Boudeuse et la flute L'Étoile. In Hérubel, M. (ed.). Paris: Union Générale d 'Éditions.

Bovis, E. de. 1980 [1855]. Tahitian Society before the Arrival of the Europeans. Laie, Hawaii: Institute for Polynesian Studies, Brigham Young University-Hawaii. $2^{\text {nd }}$ ed. Translated and introduced by Robert D. Craig.

Burley, D. G. 1998. Tongan Archaeology and the Tongan Past, 2850-150 B.P. Journal of World Prehistory 12: 337-392.

Campbell, I. C. 1989. A History of the Pacific Islands. Berkeley: University of California Press.

Campbell, I. C. 1992. Island Kingdom; Tonga Ancient and Modern. Christchurch: University of Canterbury Press. 
Claessen, H. J. M. 1970. Van vorsten en volken. (Of Princes and Peoples) $\mathrm{PhD}$ thesis, University of Amsterdam.

Claessen, H. J. M. 1978. Early State in Tahiti. In Claessen, H. J. M., and Skalník, P. (eds.), The Early State (pp. 441-468). The Hague: Mouton.

Claessen, H. J. M. 1988. Tongan Traditions; On Model Building and Historical Evidence. Bijdragen tot de Taal-, Land-en Volkenkunde 144: 433-444.

Claessen, H. J. M. 1994. Tahiti and the Early European Visitors. In Meijl T. van, and Grijp P. van der (eds.), European Imagery and Colonial History in the Pacific (pp. 14-31). Saarbrücken: Breitenbach.

Claessen, H. J. M. 1995. The Oro-maro-Arioi Connection. In Smidt, D. A. M., Keurs, P. ter, and Trouwborst, A. (eds.), Pacific Material Culture, Essays in Honour of Dr. Simon Kooijman on the Occasion of his $80^{\text {th }}$ Birthday (pp. 282-292). Leiden: Rijksmuseum voor Volkenkunde [Mededelingen 28].

Claessen, H. J. M. 2000. Ideology, Leadership and Fertility; Evaluating a Model of Polynesian Chiefship. Bijdragen tot de Taal-, Land- en Volkenkunde 154: 707-735.

Claessen, H. J. M. 2005. Chiefs and Kings in Polynesia. In Quigly, D. (ed.), The Character of Kingship (pp. 233-250). Oxford: Berg.

Claessen, H. J. M. 2015. Sacred Kingship: The African Case. Social Evolution and History 14: 3-48.

Claessen, H. J. M., and van Bakel, M. A. 2006. Theme and Variations; The Development of Differences in Polynesian Socio-Political Organizations. Bijdragen tot de Taal-, Land-en Volkenkunde 162: 218-268.

Claessen, H. J. M., and Hagesteijn, R. R. 2012. On State Formation and Territorial Expansion. Social Evolution and History 11: 3-19.

Claessen, H. J. M., and Skalník, P. (eds.) 1978. The Early State. The Hague: Mouton.

Codrington, R. H. 1969 [1891]. The Melanesians; Studies in their Anthropology and Folk-Lore. Oxford: Clarendon.

Cook, J. 1967 [1778]. Journal. In Beaglehole, J. C. (ed.), The Journals of Captain James Cook. The Voyage of the Resolution and Discovery, 17761780. Cambridge: University Press [Hakluyt Society Extra Series 36].

Cook, J. 1968 [1771]. Remarkable Occurrences on Board His Majesty's Bark Endeavour. In Beaglehole, J. C. (ed.), The Journals of Captain James Cook; The Voyage of the Endeavour, 1768-1771. Cambridge: University Press [Hakluyt Society Extra Series 34].

Cook, J. 1969 [1775]. Journal on Board His Majesty's Bark Resolution. In Beaglehole, J. C. (ed.), The Voyages of Captain James Cook; The Voyage 
of the Resolution and Adventure, 1772-1775. Cambridge: University Press [Hakluyt Society Extra Series 35].

Corney, B. G. 1915 [1775]. The Quest and Occupation of Tahiti by Emissaries of Spain during the Years 1772-1776. Told in Despatches and Other Contemporary Documents. Vol. 2. London: Cambridge University Press [Hakluyt Society Second Series 36].

Cummins, H. G. 1977. Tongan Society at the Time of European Contact. In Rutherford, N. (ed.), Friendly Islands; A History of Tonga (pp. 63-89). Melbourne: Oxford University Press.

Dentrecasteaux, J. A. B. 1808. Voyage de Dentrecasteaux, envoyé à la recherche de La Pérouse. 2 vols. In de Rossel, E. P. E. (ed.). Paris: Impremerie Impériale.

Dorsenne, J. 1929. Avant propos. In C. F. P. Fesche (ed.), La Nouvelle Cythère (Tahiti), Journal de navigation inédit. Paris: Duchartre \& Van Buggenhoudt.

Dumont d'Urville, J. S. C. 1832. Voyage de la corvette l'Astrolabe, exécuté par ordre du Roi, pendant les Années 1826, 1827, 1828, 1829, sous le commandement de M. Dumont d'Urville, capitaine de vaisseau. Histoire $d u$ voyage. 5 vols. Paris: Gide.

Ellis, W. 1831. Polynesian Researches, During a Residence of Nearly Eight Years in the Society and Sandwich Islands. 4 vols. London: Fischer, Son, and Jackson.

Firth, R. 1963 [1936]. We, the Tikopia. Kinship in primitive Polynesia. Boston: Beacon Press.

Firth, R. 1967. Tikopia Ritual and Belief. Boston: Beacon Press.

Flannery, K., and Marcus, J. 2012. The Creation of Inequality. How our Prehistoric Ancestors Set the Stage for Monarchy, Slavery, and Empire. Cambridge, MA: Harvard University Press.

Forster, G. 1983 [1778-80]. Reise um die Welt. In G. Steiner (ed.). Frankfurt am Main: Insel Verlag.

Forster, J. R. 1996 [1778]. Observations Made during a Voyage Round the World. In Thomas, N., Guest, H., and Dettelbach, M. (eds.). Honolulu: University of Hawaii Press.

Gifford, E. W. 1971 [1929]. Tongan Society. Honolulu: Bishop Museum Press [B. P. Bishop Museum Bulletin 61].

Goldman, I. 1970. Ancient Polynesian Society. Chicago: University of Chicago Press.

Grinin, L. 2003. The Early State and its Analogues. Social Evolution and History 2: 131-176.

Grinin, L. 2009. The Pathways of Politogenesis and Models of Early State Formation. Social Evolution and History 8: 92-132. 
Grinin, L. 2011. Complex Chiefdom: Precursor of the State or its Analogue? Social Evolution and History 10: 234-275.

Henry, T. 1951 [1928]. Tahiti aux temps anciens. Translated by B. Jaunez. Paris: Musée de l'Homme. [Publications de la Société des Océanistes 1].

Herda, P. 1990. Genealogy in the Construction of Tongas Past. In Herda, Ph., Terrell, J., and Gunson, N. (eds.), Tongan Culture and History (pp. 2129). Canberra: Research School of Pacific Studies. Australian National University.

Irwin, G. 1992. The Prehistoric Exploration and Colonization of the Pacific. Cambridge: University Press.

Kaeppler, A. L. 1971. Rank in Tonga. Ethnology 10: 174-193.

Kirch, P. V. 1984. The Evolution of Polynesian Chiefdoms. Cambridge: University Press [New Studies in Archaeology].

Kirch, P. V. 1988. Circumscription Theory and Sociopolitical Evolution in Polynesia. American Behavioral Scientist 31: 416-427.

Kirch, P. V. 1997. The Lapita Peoples. Ancestors of the Oceanic World. Cambridge: University Press [School of American Research, Advanced Seminar Series].

Kirch, P. V., and Green R. C. 2001. Hawaiki, Ancestral Polynesia. An Essay in Historical Anthropology. Cambridge: University Press.

Koch, G. 1955. Südsee gestern und heute. Der Kulturwandel bei den Tonganern und ein Versuch einer Deutung dieser Entwicklung. Braunsweich: Limbach [Kulturgeschichtliche Forschungen 7].

Labillardière, J. H. J. de. 1800. Relation du voyage à la recherche de La Pérouse, fait par ordre de l Assemblée Constituante, pendant les années 1791 et 1792, et pendant la lère et $2^{e}$ année de la République Française. 2 vols. Paris: Jansen.

Lehmann, F. R. 1915. Mana. Eine begriffsgeschichtliche Untersuchung auf ethnologischer Grundlage. PhD thesis University of Leipzig.

Lindstrom, L. 1996. Mana. In Barnard, A., and Spencer, J. (eds.), Encyclopedia of Social and Cultural Anthropology (pp. 346). London: Routledge.

Mariner, W. 1819. Nachrichten über die Freundschaftlichen, oder die TongaInseln. Aus den Mitteilungen desselben zusammengetragen und herausgegeben von J. Martin. Weimar: Landes Industrie Comptoirs. [Neue Bibliothek der wichtigsten Reisebeschreibungen zur Erweiterung der Erd- und Völkerkunde 20].

Maurelle, F. A. 1782 [1797]. Relation d; un voyage intéressant de la frégate la Princesse, de Manille à Saint-Blaise, en 1780 et 1781 . In Milet-Mureau, L. A. (ed.), Voyage de la Pérouse autour du Monde, publié conformément au Décret du 22 avril 1791 à Paris. 
McArthur, N. 1968. Island Populations of the Pacific. Canberra: Australian National University Press.

McKern, W. C. 1929. Archaeology of Tonga. Honolulu: Bishop Museum Press [Bernice P. Bishop Museum Bulletin 60].

Moerenhout, J. A. 1837. Voyages aux îles du Grand Océan. Contenant des documents nouveaux sur le géographie physique et politique, la langue, la literature, la religion, les moeurs, les usages etr les coutumes de leurs habitants. Et des considerations générales sur leur commerce, leur histoire et leur gouvernements, depuis les temps les plus reculés jusqu'à nos jours. 2 vols. Paris: Bertrand.

Moschner, I. 1966. Introduction to Missionary Voyage to the Southern Pacific Ocean by J.Wilson. pp. i-xix. Graz: Akademische Druck- und Verlagsanstalt. See also under James Wilson 1799.

Morrison, J. 1966 [1792]. Journal de James Morrison; Second Maître à bord de la Bounty. Traduit de l'Angais par B. Jaunez. Paris: Musée de l'Homme [Publications de la Société des Océanistes 16].

Oliver, D. 1974. Ancient Tahitian society. 3 vols. Honolulu: University Press of Hawaii.

Oliver, D. 1988. Return to Tahiti: Bligh's Second Breadfruit Voyage. Honolulu: University of Hawaii Press.

Oliver, D. 2002. Polynesia in Early Historic Times. Honolulu: Bess Press.

Pérouse, J.-F. de Galaup de la. 1994/95 [1788]. In Dunmore, J. (ed.), The Journal of Jean-François de Galaup de la Pérouse. 1785-1788. London: The Hakluyt Society [ $2^{\text {nd }}$ Series 179,180$]$.

Poulsen, J. 1977. Archaeology and Prehistory. In Rutherford, N. (ed.), Friendly Islands. A History of Tonga (pp. 4-26). Melbourne: Oxford University Press.

Robertson, G. 1948 [1768]. A Journal of the Second Voyage of H. M. S. Dolphin round the World, under Command of Captain Wallis R. N., in the Years 1766, 1776, 1768, written by her master George Robertson. In Carrington, H. (ed.), The Discovery of Tahiti (pp. 3-255). London: Cambridge University Press [Hakluyt Society, $2^{\text {nd }}$ Series 98].

Rodriguez, M. 1995 [1776]. Les Espagnols à Tahiti (1772-1776). Transl. by H. Belçaguy. Paris: Musée de l'Homme. [Publications de la Société des Océanistes 45].

Rogers, G. 1977. The Father's Sister is Black: A Consideration of Female Rank and Power in Tonga. Journal of the Polynesian Society 86: 157-182.

Rose, R. G. 1978. Symbols of Sovereignty; Feather Girdles of Tahiti and Hawaii. Honolulu: Department of Anthropology, Bishop Museum [Pacific Anthropological Records 28]. 
Sahlins, M. D. 1972 [1958]. Social Stratification in Polynesia. Seattle: University of Washington Press.

Thomas, N. 1990. Marquesan Societies; Inequality and Political Transformation in Eastern Polynesia. Oxford: Clarendon.

Thomas, N. 2003. Discoveries. The Voyages of Captain Cook. London: Allen Lane.

Thomson, B. 1894. The Diversions of a Prime Minister. London: Blackwood.

Turnbull, J. 1806. Reise um die Welt, oder eigentlich nach Australien in den Jahren 1800-1804. In Erdmann, T. F. (ed.). Weimar: Landes Industrie Comptoirs [Bibliothek der neuesten und wichtigsten Reisebeschreibungen 29].

Tymowski, M. 2009. The Origins and Structures of Political Institutions in Pre-Colonial Black Africa. Lewiston: Edwin Mellen Press.

Wilson, J. 1799. A Missionary Voyage to the Southern Pacific Ocean, performed in the years 1796, 1797, 1798, in the Ship Duff. London: Chapman. 